\title{
Pele de asno: do texto ao contexto
}

\author{
Donkey skin: from text to context
}

\section{Piel de asno: del texto al contexto}

\author{
iD (9) Ana Carolina Stakonski \\ Universidade Federal da Fronteira Sul (UFFS), Erechim, Rio Grande do Sul, Brasil. \\ E-mail: nina_stakonski@hotmail.com \\ iD Ivone Maria Mendes Silva \\ universidade Federal da Fronteira Sul (UFFS), Erechim, Rio Grande do Sul, Brasil. \\ E-mail: ivonemmds@gmail.com
}

Resumo: Este artigo analisa o conto Pele de asno, de Charles Perrault, buscando compreender a infância e a sexualidade configuradas no contexto histórico de compilação dessa produção. O estudo permitiu constatar que, naquele contexto, ainda que houvesse um questionamento e reprovação crescentes das atividades sexuais entre crianças e adultos ou de práticas como o incesto, estas não eram incomuns e continuaram sendo retratadas nos contos para as crianças. Cabe notar que a percepção até então construída sobre a infância não tinha como cerne a preocupação com cuidados baseados em preceitos morais, educativos e protetivos como os valorizados na atualidade.

Palavras-chave: Contos de Fada. Infância. Sexualidade. Contexto histórico.

\begin{abstract}
This article analyzes the story Pele de asno, by Charles Perrault, seeking to understand childhood and sexuality configured in the historical context of the compilation of this production. The study showed that, in that context, even though there was an increasing questioning and disapproval of sexual activities between children and adults or practices
\end{abstract}


such as incest, these were not uncommon and continued to be portrayed in the children's stories. It should be noted that the perception built up until then about childhood was not at the heart of the concern with care based on moral and educational precepts such as those currently valued.

Keywords: Fairy Tales. Childhood. Child sexuality. Historical context.

Resumen: Este artículo analiza la historia Pele de asno, de Charles Perrault, buscando comprender la infancia y la sexualidad configuradas en el contexto histórico de la recopilación de esta producción. El estudio mostró que, en ese contexto, a pesar de que había un creciente cuestionamiento y desaprobación de las actividades sexuales entre niños y adultos o prácticas como el incesto, estas no eran infrecuentes y seguían siendo retratadas en los cuentos infantiles. Cabe señalar que la percepción construida hasta entonces sobre la infancia no estaba en el centro de la preocupación por el cuidado basado en preceptos morales y educativos como los que se valoran actualmente.

Palabras clave: Cuentos de Hada. Infancia. Sexualidad infantil. Contexto histórico.

Submetido em 16 de janeiro de 2020.

Aceito em 04 de agosto de 2020.

Publicado em 04 de junho de 2021. 


\section{Introdução}

Os contos de fadas são artefatos profícuos para a análise das modificações nas representações sobre infância e sexualidade, uma vez que as primeiras versões que se tornaram populares no mundo ocidental foram escritas em um momento histórico de grandes mudanças sociais que se refletiram em vários processos, incluindo os dois citados (RADINO, 2003). Tendo em vista essas questões, o presente estudo busca utilizar a análise do conto Pele de asno como recurso para compreender a sexualidade e a infância configuradas no contexto histórico de compilação e escrita dessa produção por Perrault.

A forma como lidamos com a infância, assim como com a sexualidade, foi variando concomitantemente com as censuras colocadas nos contos de fadas por educadores preocupados com a preservação das crianças (CORSO; CORSO, 2006). Tal representação social de infância que censura conteúdos voltados para as crianças direciona o modo como elas são educadas. Considerando isso, busca-se compreender como o conto Pele de asno retrata a infância e o que ele traz em relação à sexualidade, tendo em vista as influências sociais presentes no período histórico em que foi escrito.

\section{Metodologia}

Tendo como principal objetivo analisar como, no conto Pele de asno, a sexualidade e a infância são representadas e relacionadas, esta pesquisa qualitativa se organiza em duas etapas: a primeira refere-se ao estudo bibliográfico, que busca trabalhos acadêmicos com o intuito de definir conceitos utilizados na pesquisa. Para tal análise, lançamos mão de um aporte teórico que engloba pesquisadores das áreas da psicanálise e da história, no intuito de 
compreender o contexto de escrita do conto, bem como a forma como o tema da sexualidade é nele abordado. Para a abordagem do tema infância, baseamo-nos primordialmente nas produções de Ariès (2014), Corazza (2002) e Heywood (2004); no tocante à sexualidade, utilizamos como principais autores Freud (1905/1976) e Méllo (2006); e ao nos referirmos aos contos de fadas, Canton (2009), Corso e Corso (2006), Darnton (2015) e Radino (2003).

Já a segunda etapa tem como foco a análise do conto Pele de Asno, na busca por identificar o contexto histórico de sua produção escrita (sem perder de vista o fato de que o conto provém da tradição oral) para, assim, compreender as representações de infância e sexualidade predominantes na realidade utilizada como referência por Charles Perrault. Tal proposta reconhece "a capacidade inerente aos textos ficcionais em construir afinidades e entrelaces com o real" (FERREIRA, 2015, p. 2), pois entende que a literatura expõe aspectos que podem ser estudados para a compreensão da realidade social e histórica. Assim, foram verificados trechos do conto a partir dos quais se analisou o contexto histórico que serve de pano de fundo para a construção de determinadas representações de infância e sexualidade.

Estratégia metodológica semelhante foi utilizada em outros trabalhos precedentes, como em Andrade (1996), Carvalho (2009), Darnton (2015), Debald, Silva e Oliveira (2013), dentre outros. Ao ler esses trabalhos, percebe-se que compreender o contexto histórico de produção dos materiais literários é de grande importância para identificar os valores e as representações vigentes na época.

Para melhor esclarecer a colocação anterior, Debald, Silva e Oliveira (2013, p. 68) afirmam que "o mundo da fantasia reproduz um contexto histórico produzido por pessoas que se utilizam de tal recurso para perpetuar seus costumes e tradições". Partindo desse pressuposto, pode-se refletir sobre as possíveis modificações de valores e crenças que ocorreram com o passar do tempo, do século XVII para a atualidade, por exemplo, sem deixar de considerar os processos históricos e sociais necessários para as reestruturações desses valores. 
Para Darnton (2015, p. 26), "os contos populares são documentos históricos" que "surgiram ao longo de muitos séculos e sofreram diferentes transformações, em diferentes tradições culturais". Concordando com Darnton (2015), Andrade (1996) também reconhece a potencialidade dos contos como objeto de análise histórica, pois ainda que sejam narrativas ficcionais, ecoam características do contexto histórico no qual foram escritos e da tradição oral da qual são provindos.

Carvalho (2009) e Debald, Silva e Oliveira (2013) expõem a possibilidade de as narrativas serem utilizadas para a compreensão do contexto vivido no momento da criação das histórias. Darnton (2015, p. 17), por sua vez, afirma que é possível "extrair a significação" dos contos de fadas para passar "do texto ao contexto" e compreendê-lo através de interpretações.

Charles Perrault foi escolhido como autor foco da pesquisa porque foi o primeiro a registrar na forma escrita os contos de fadas que conhecemos hoje. Mas a infância retratada nos contos de Perrault é distinta daquela que conhecemos hoje. Essa diferença chama a atenção para a necessidade de se estudar a realidade de tal período histórico. O conto Pele de asno foi escolhido, entre outras possibilidades, por causar um forte estranhamento ao sentimento de infância ocidental moderno devido ao enredo e às personagens nele presentes. Além disso, esse conto amplia as possibilidades de construção de uma análise voltada às representações sobre infância e sexualidade. Nesse sentido, o conto foi utilizado como "documento histórico" (DARNTON, 2015, p. 26) para entender o contexto da época em que foi escrito por Perrault - passagem do século XVII ao XVIII.

Seguindo as orientações propostas por Ferreira $(2015$, p. 3), foram abordadas também "duas dimensões de análise: intratextual, dedicada ao estudo interno do texto, e intertextual, que coteja tanto o contexto da produção da obra quanto o texto literário, sendo que ambas as propostas metodológicas estão imbricadas". A análise exige uma busca na literatura acadêmica com o intuito de compreender o contexto histórico para fundamentar a pro- 
Pele de asno: do texto ao contexto

Ana Carolina Stakonski • Ivone maria mendes silva

posta dessa segunda etapa, bem como a interpretação dos textos, com foco na identificação de fragmentos que ofereçam pistas para o estudo do contexto.

\section{Erauma vez...:Representações de infância e sexualidade nos contos de fadas}

\subsection{Infância e sexualidade}

Na atualidade, a infância costuma ser considerada a faixa etária "que molda o caráter e o destino de um indivíduo" (HEYWOOD, 2004 , p. 10). Tal concepção faz com que as crianças sejam consideradas sujeitos de direitos próprios, com particularidades percebidas, preservadas e respeitadas. Segundo Heywood (2004, p. 12), "acabamos por associar a infância, em termos gerais, a características como a inocência, vulnerabilidade e assexualidade". Porém, essa representação de infância, difundida na atualidade em grande parte das culturas, nem sempre foi assim.

Por muito tempo os historiadores não se preocuparam em buscar aspectos da infância, tornando as crianças "as grandes ausentes da história" (CORAZZA, 2002, p. 82). Partindo desse pressuposto, percebe-se que as buscas teóricas que levam em conta essa faixa etária são muito recentes. Entretanto, uma dessas pesquisas obteve, segundo Corazza (2002, p. 82), "a mais importante contribuição ao campo de sua história". Essa colocação da autora é concedida à pesquisa de Phillipe Ariès, que mesmo sendo criticado por diversos autores é considerado um clássico por intelectuais e pesquisadores da história da infância.

O estudo desse autor é centrado na análise da arte do período medieval. Usando tal metodologia, Ariès (2014) percebe a falta de representação do sujeito infantil. Expõe ainda que, quando a criança aparecia, era idêntica ao adulto em vários sentidos. O traço que os diferenciava era somente a estatura, o que fazia as crian- 
ças parecerem "miniaturas" (ARIÈS, 2014, p. 17). O autor defende também que, na sociedade medieval, o "sentimento de infância" era inexistente. $\mathrm{O}$ uso dessa expressão é justificado por ele com a argumentação de que "não significa o mesmo que afeição pelas crianças: corresponde à consciência da particularidade infantil, essa particularidade que distingue essencialmente a criança do adulto, mesmo jovem" (ARIÈS, 2014, p. 99).

Nessa perspectiva, logo após não ter necessidade do adulto para sua sobrevivência, a criança era inserida na sociedade adulta, participando de todas as práticas exercidas ali. Discutindo essa questão, Heywood (2004, p. 23) argumenta que, para Ariès, "a civilização medieval não percebia um período transitório entre a infância e a idade adulta". Assim, a criança ou era um bebê, que precisava ser alimentado, ou então um adulto, sem que o processo entre essas etapas da vida fosse percebido. Nesse sentido, "a duração da infância era reduzida a seu período mais frágil" (ARIÈS, 2014, p. 9), ou seja, aos primeiros anos de vida da criança.

Assim, a própria família não se organizava nos moldes modernos ocidentais, não exercia o papel de assegurar os cuidados com as crianças e grande parte dos aprendizados destas eram adquiridos sem que a família os mediasse (ARIÈS, 2014). Os infantes da época obtinham seus saberes fazendo as atividades como os próprios adultos, junto com eles. Para tanto, a criança era cuidada pelos pais e pela sociedade por um período de tempo bastante breve, que não era o suficiente para criar vínculos fortes entre os familiares e a criança.

Darnton (2015) argumenta ainda que anteriormente aos séculos XVII e XVIII, em épocas de frio intenso, era comum os camponeses dormirem todos na mesma cama, para juntos esquentarem seus corpos. As crianças viam e presenciavam momentos em que seus pais tinham relações sexuais. Esse exemplo exposto por Darnton (2015) mostra a distância dessa representação conferida à infância e em sua relação com a sexualidade presente no período histórico por ele mencionado para a concepção mais difundida atualmente na cultura ocidental. É importante destacar que, ainda que esse tipo 
de prática ocorra atualmente em algumas famílias e os significados a elas atribuídos possam variar, as representações hegemônicas sobre a relação entre esses processos (infância e sexualidade) são, de fato, diferentes hoje.

Sob a influência do pensamento de Ariès (2014), pode-se afirmar que a criança medieval não tinha importância social, "era, no máximo, uma figura marginal em um mundo adulto" (HEYWOOD, 2004 , p. 10). Essa realidade foi se modificando historicamente e moldando-se socialmente. Desse modo, para compreender a infância é necessário ter clareza de todo o processo de reorganização na representação social, acontecido historicamente, visando à construção social da infância e percebendo que nem todas as sociedades são iguais. Como evidencia Heywood (2004), sociedades diferentes representam a infância de formas distintas.

Essa distância temporal é percebida por Ariès (2014), que expõe fragmentos de textos antigos com frases que confrontam fortemente a representação atual de infância. Essas frases demonstram o desapego dos pais com seus filhos, já que a taxa de mortalidade na época era bastante elevada. Até chegar a certa idade as crianças nem eram contadas, pois grande parte delas não sobrevivia. Segundo Ariès (2014, p. 22), "não se pensava, como normalmente acreditamos hoje, que a criança já contivesse a personalidade de um homem", mas sim em um momento frágil a ser superado se a ele o indivíduo sobrevivesse.

Quando superava essa condição, o que era pouco provável, a criança era inserida na vida adulta. Radino (2003) constata que, nesse período, em famílias muito pobres, as crianças eram vistas como mais uma boca para alimentar, o que acabava agravando a miséria dos pais, que obtinham poucos recursos para seu sustento. "Um novo filho, muitas vezes, significava a diferença entre a pobreza e a indigência" (DARNTON, 2015, p. 44).

Segundo Radino (2003), nesse período era comum o abandono dos filhos, a situação crítica dos órfãos, o descaso das madrastas e até a fome, todos retratados em vários contos de fadas. Ariès 
(2014, p. 15) expõe que no período estudado por ele ocorria o que o autor denomina de "infanticídio tolerado". Essa prática era considerada um crime passível de punição, porém ocorria de forma a simular acidentes. Uma forma de fazê-lo, exposta por Ariès (2014), era asfixiar a criança na cama dos pais enquanto dormia. Essa prática "de ajudar a natureza a fazer desaparecer criaturas tão pouco dotadas de um ser suficiente" (ARIÈS, 2014, p. 15) diminuiu muito depois que a infância passou a ser ligada às práticas educativas.

No que segue o século XVII, a construção da ideia de infância tem avanços significativos, o que possibilita a observação de aspectos que se assemelham à representação atual do papel da criança e da sociedade em relação a ela. Obviamente que a percepção da infância faz parte de um processo de reestruturação social, e isso não se modifica de um momento para outro, leva anos, décadas e até mesmo séculos.

Somente a partir do século XVII que as instituições escolares passam a assumir um papel central na socialização e transmissão de saberes para as crianças. Dessa forma, o período de escolarização entre os primeiros anos e a idade considerada adulta tornase mais um fator de diferenciação social entre as crianças e os adultos, reconhecendo-se a infância como a fase durante a qual as crianças deveriam ser educadas e protegidas do "mundo adulto". Para Ariès (2014), essa consideração com a educação gerou uma afeição familiar, pois os pais, importando-se com a educação dos filhos, mantinham mais contato com eles e os acompanhavam zelosamente.

A partir dessa época, passa a existir certa preocupação com o desenvolvimento psicológico e moral das crianças em prol de sua educação. Elas passam a ser percebidas como criaturas de Deus, mostrando a influência cristã e dos valores sociais dominantes. Associada a isso, emerge uma atenção crescente para com as etapas do desenvolvimento das crianças e com a maneira de educar em cada uma dessas etapas. Processo que acabou sendo influenciado também pelo surgimento de áreas de estudo científico como a pediatria, a psicologia e a sociologia, as quais possuem atual- 
mente uma tradição consolidada na abordagem do tema, a partir de vertentes teóricas diversas. Entre elas, vertentes que atualmente chamam a atenção para a necessidade de considerar que as chamadas fases do desenvolvimento infantil não acontecem da mesma forma para todas as crianças, pois a cultura, a classe social, o gênero, entre outros processos sociais, interferem nas experiências de infância.

Outro cuidado necessário é com a ideia da função social da infância, pois o que se pode deduzir a partir das observações da vida cotidiana é que, muitas vezes, a vida adulta é vista como "etapa fundamental da vida" (HEYWOOD, 2004, p. 11) e a infância como etapa em que o caráter é moldado. Frequentemente, essa ideia faz com que a infância e a adolescência sejam consideradas pontes para a vida adulta. E, nessa lógica, crianças e adolescentes passam a ser preparados para seu futuro no sentido de "transformar a criança imatura, irracional, incompetente, associal e acultural em um adulto maduro, racional, competente, social e autônomo" (HEYWOOD, 2004, p. 11). Assim, segundo Corso e Corso (2006), a infância precisa ser vista como uma etapa da vida e não como incompetência. Para tanto, as crianças "devem ser consideradas como partes ativas na determinação de suas vidas e das vidas daqueles que estão ao seu redor" (HEYWOOD, 2004, p. 12).

Essas ponderações indicam que a representação de infância não é algo estático; cada sociedade, época ou grupo social distinto pode moldar uma representação de infância, bem como de sexualidade, com características que destoam das concepções vigentes em outros contextos socioculturais e históricos. Nesse sentido, percebe-se que os seres humanos são sociais e históricos, assim como as representações e práticas que constroem.

Discorrendo mais sobre a sexualidade, pode-se afirmar que esta, assim como a infância, é "uma invenção social" (LOURO, 2010). A forma como a sexualidade é compreendida e vivida depende do momento histórico e da cultura. Portanto, a sexualidade tem uma dimensão social, ou seja, varia conforme o gênero, raça, cultura, religião, idade. A própria relação subjetiva com a sexua- 
lidade está inteiramente relacionada com sua concepção social (LOURO, 2010).

Em complemento a essa perspectiva, mostra-se relevante a referência às contribuições que a psicanálise traz a essa discussão, especialmente seu pressuposto de que o sexual não se restringe ao genital. Como esclarecem Laplanche e Pontalis (2001), ao buscarem definir o que a psicanálise entende por sexualidade,

Na experiência e na teoria psicanalíticas, "sexualidade" não designa apenas as atividades e o prazer que dependem do funcionamento do aparelho genital, mas toda uma série de excitações e de atividades presentes desde a infância, que proporcionam um prazer irredutível à satisfação de uma necessidade fisiológica fundamental (respiração, fome, função de excreção, etc.), e que se encontram a título de componentes na chamada forma normal de amor sexual. (LAPLANCHE; PONTALIS, 2001, p. 476).

Em Três ensaios sobre a teoria da sexualidade, Freud (1905/1976) discorre sobre a sexualidade infantil, considerando-a um elemento-chave para a compreensão psicanalítica a respeito do assunto. Nessa obra, o autor argumenta que o ser humano é dotado de sexualidade desde o nascimento para, na sequência, descrever diversas manifestações da sexualidade infantil, construídas por meio da relação que a criança estabelece com seu próprio corpo e com o corpo de outras pessoas e do engajamento em atividades diversas, capazes de lhe conferirem prazer (FREUD, 1905/1976).

Ao considerar os vínculos afetivos e os desejos sexuais que a criança pode nutrir em relação a outras pessoas, Freud (1924/1996) formula o conceito de Complexo de Édipo, que remete aos sentimentos de amor e ódio (ou "ambivalência emocional") experimentados pelos sujeitos infantis na relação com os próprios pais. A chamada fase "fálica" ou "genital", vivida entre os três e os cinco anos de idade aproximadamente, seria o período da infância no qual essas questões emergiriam. Ao formular o conceito, ele reconhece que a proibição cultural do incesto é assimilada pela criança 
ao final desse processo, quando esta apreende as normas morais vigentes na sociedade em que se insere por intermédio dos ensinamentos de seus pais. Tem-se, assim, a formação do superego, que corresponde à internalização dessas normas sociais. Nas palavras do autor:

A autoridade do pai ou dos pais é introjetada no ego e aí forma o núcleo do superego, que assume a severidade do pai e perpetua a proibição deste contra o incesto [...]. As tendências libidinais pertencentes ao complexo de Édipo são em parte dessexualizadas e sublimadas (coisa que provavelmente acontece com toda transformação em uma identificação) e em parte são inibidas em seu objetivo e transformadas em impulsos de afeição. (FREUD, 1924/1996, p. 221).

É também em Totem e Tabu (1924/1996) que Freud explana sobre as origens da exogamia, constatando uma certa inclinação dos pesquisadores a concluírem que o "horror ao incesto" aparece ligado a um instinto inato. No entanto, o autor discorda de tal ponto, expressando a ideia de que um instinto inato não necessita de proibição legal. Tendo em vista tal pressuposto, Freud (1924/1996) defende que a aversão à prática incestuosa tem origens históricas ligadas aos povos primitivos e que a própria civilização humana se constitui calcada no horror ao incesto.

Com isso, podemos entender que o incesto se faz presente em diferentes culturas, mas, em algumas delas, são construídos por meio de processos socioculturais e históricos, preceitos que sustentam sua proibição, os quais, uma vez assimilados pelos indivíduos, condiciona-os a reprimirem certos desejos e práticas sexuais.

\subsection{Contos de fadas e seus autores}

De acordo com Hillesheim e Guareschi (2006), a palavra conto é derivada do latim fabula e, a partir dessa derivação, percebem-se 
dois significados: a oralidade e a ficcionalidade. Consequentemente, conto significa um relato que não faz parte da realidade e que é difundido através da oralidade (HILLESHEIM; GUARESCHI, 2006). Assim como o conto, a palavra fada deriva do latim fatum, que significa destino (RADINO, 2003). As fadas dominam a magia e simbolizam a capacidade da imaginação de desejos que não se pode realizar. Dominam também os mistérios da vida que perpassam desde o nascimento até a morte - o destino (RADINO, 2003).

Os contos de fadas são narrativas inicialmente orais, que usam elementos mágicos para retratar histórias que representam algumas situações da vida cotidiana. Durante vários séculos, antes de existirem livros ou escolas, o conhecimento era construído por meio da oralidade. Mesmo atualmente, todo ser humano adquire seus primeiros saberes a partir dela. Foi com o uso dessa oralidade que os contos de fadas foram difundidos (RADINO, 2003).

Os contos de fadas clássicos conhecidos atualmente nasceram - em grande parte - na França e na Alemanha, entre os camponeses e, infelizmente, são anônimos e não podem ser datados pelo conteúdo folclórico que abordam. As versões escritas, mesmo as mais precisas, não abrangem o conteúdo narrativo dos contadores de história da época (DARNTON, 2015). A tradição oral desses camponeses mostrou seu forte poder de resistência, pois embora emergindo em um tempo em que o analfabetismo prosperava, os contos se mantinham muito parecidos de um século para outro (DARNTON, 2015).

Mesmo com a impossibilidade de serem fiéis à toda a herança cultural abarcada nas versões orais, as narrativas escritas atravessaram gerações até a atualidade e, apesar das inúmeras modificações sofridas, têm uma base comum, visto as relações e semelhanças que podem ser identificadas entre versões distintas do mesmo conto. Por outro lado, as diferenças existentes entre as várias versões expressam mudanças sociais ocorridas durante os séculos, trazendo a constatação de que as mentalidades não são universais; elas transformam-se conforme o momento histórico e 
a cultura, sendo os contos populares "documentos históricos" que guardam em si registros desses processos (DARNTON, 2015, p. 26).

Os contos de fadas da tradição oral retratavam um mundo de brutalidade de forma explícita (DARNTON, 2015). Expressavam a inconformidade dos costumes feudais (HILLESHEIM; GUARESCHI, 2006) e, assim, os camponeses utilizavam a ficção para manifestar-se contra a opressão sofrida nesse período (RADINO, 2003).

A organização feudal obrigava os camponeses a pagar grandes quantidades de impostos, dízimos e tributos senhoriais, o que os transportava a um "estado de subnutrição crônica" (DARNTON, 2015 , p. 40). Essa organização aristocrata trazia a necessidade de lutar por recursos escassos e sobrevivência, condição que propiciava o "ódio, inveja e conflitos de interesses" (DARNTON, 2015, p. 42).

Lembrando que os contos de fadas nasceram nessa realidade, podemos perceber que a busca por comida, e até mesmo o infanticídio, aparecem em vários contos de Perrault. Darnton (2015, p. 47) evidencia que os camponeses "habitavam um mundo de madrastas e órfãos, de labuta inexorável e interminável, e de emoções brutais, tanto aparentes como reprimidas", o que permite perceber que os contos têm suas raízes na realidade da época. Essas emoções brutais citadas por Darnton (2015) tornavam comum uns matarem os outros, deixando crianças órfãs. Da mesma forma, a orfandade ocorria pela morte da mãe em complicações no parto, o que fazia com que o pai buscasse outra mulher.

Esse fato pode parecer incoerente quando pensamos no público-alvo dessas narrativas na atualidade, porém é preciso termos em vista que, inicialmente, não havia o propósito de direcionar os contos às crianças. Nesse período, a criança não tinha importância social que a tornasse particular, não havia cuidados com a escolha de conteúdo específico para ela. As narrativas eram contadas sem diferenciação de idade (CORSO; CORSO, 2006).

Charles Perrault foi pioneiro na compilação dos contos de fadas que são tão famosos atualmente, buscando registrar a cultura do povo local. No entanto, ele não foi fiel em seus registros, 
modificando-os, omitindo elementos pagãos e censurando cenas explícitas de sexualidade. Ele adaptava os contos conforme a necessidade da corte francesa.

O contexto histórico dos registros de Perrault abarca o reinado de Luís XIV, que "criou valores sociais, incentivou a difusão cultural e a liderança política necessárias para a expansão europeia" (RADINO, 2003, p. 73). Nesse reinado, criaram-se alguns salões para as reuniões de convidados da corte, os quais, com o crescente número de intelectuais, foram aumentando cada vez mais e sendo compostos por um público bastante culto. Como forma de diversão e distração, nesses salões eram lidos "versos, rimas, contos de fadas" (RADINO, 2003, p. 74), o que levou os contos de fadas a se tornarem um "fenômeno social" da classe social idealizada (RADINO, 2003, p. 75).

De acordo com Radino (2003), Luís XIV gostava muito de contos de fadas e, por isso, ao registrar os contos da tradição oral da época, Perrault adaptou as narrativas para agradar e refletir alguns ideais da corte de Luís XIV. Para tanto, "os rituais medievais foram omitidos e a sexualidade pública foi substituída pelo recato e a intimidade" (RADINO, 2003, p. 78).

As cenas dos contos de fadas situam-se em uma realidade feudal, mas os valores ali expostos representam a burguesia em ascensão, já que o próprio autor era um burguês aceito na sociedade mais nobre por seu conhecimento intelectual (RADINO, 2003). Nesse processo histórico, a burguesia ascendeu socialmente e, ao mesmo tempo, uma nova concepção de infância estava se consolidando (RADINO, 2003).

O público infantil identificou-se com essas narrativas, levando os autores a adaptarem seus textos para esse público. Aos poucos, esse público passou a ser reconhecido como particular, requerendo textos que abrangessem essa particularidade. Quanto mais os contos de fadas iam se aproximando dessa faixa etária, mais iam sendo censurados, de acordo com os ideais da classe social dominante (RADINO, 2003). 
Com a publicação de Pele de asno, em 1696, Perrault começa a voltar seus contos para as crianças (HILLESHEIM; GUARESCHI, 2006), demonstrando que, apesar de inicialmente não sustentar a intenção de escrever para elas, desenvolveu aos poucos a preocupação de adaptar sua escrita a esse público (RADINO, 2003), mostrando sua percepção da particularidade da infância.

Observando a vulgaridade dos contos, Perrault ocultou alguns aspectos com símbolos, deixando mais forte a linguagem simbólica. Para defender suas narrativas do mau julgamento social, Perrault acrescentou algumas morais da história nos contos (HILLESHEIM; GUARESCHI, 2006). A partir dessas morais, pode-se observar o intuito de civilizar as crianças, pois aspectos como o bem, a obediência, a ingenuidade feminina, a força masculina, entre outros, são louvados, e o mal é punido. A partir desse momento, muitos contos de fadas passaram a ter um final feliz, ou então uma lição de moral conscientizadora sobre a importância da obediência e de outros aspectos valorizados na época.

Apesar da tentativa de Perrault de adequar os contos para a infância, percebe-se, ao ler seus registros, que ainda há uma distância destes em relação ao que atualmente é considerado apropriado ou desejável para essa faixa etária. Nestes registros podem ser observados alguns elementos que hoje são considerados do mundo adulto ou inadequados para crianças e que, por isso, acabaram sendo censurados e/ou adaptados em relação à estrutura original do conto.

Para Corso e Corso (2006), as narrativas atuais são como heranças, deixadas pela criação da família nuclear e pela invenção da infância. Os autores defendem que as ideias iluministas, obtidas a partir das revoluções burguesas, colocam a criança como sujeito com direitos específicos, conquistados desde a Revolução Industrial. Por conseguinte, pode-se perceber que as mutações na representação de infância e nos contos de fadas são concomitantes.

Os contos de fadas não são narrativas atemporais (CANTON, 2009; DARNTON, 2015), mas sim histórias que, a partir de suas 
Pele de asno: do texto ao contexto

Ana Carolina Stakonski • Ivone maria mendes silva

múltiplas versões, demonstram a forma como o pensamento humano foi se modificando ao longo do tempo. Com cunho folclórico, os contos de fadas, muitas vezes, possuem autores anônimos e se mostram cheios de possibilidades de superar a triste realidade, trazidas por meio de símbolos. Os contos, desde suas raízes, expressam os desejos mais profundos da humanidade que, geralmente, são satisfeitos: "ao menos nos contos, uma camponesa podia se transformar em princesa, com a ajuda mágica de uma fada, e quem sabe até viver feliz para sempre" (CANTON, 2009, p. 10).

\section{Análise do conto Pele de asno}

Charles Perrault, como já exposto, não tinha, inicialmente, a intenção de direcionar seus contos especificamente para o público infantil, dado o contexto histórico da época, em que a função social da infância não era totalmente percebida como distinta. Porém, é possível notar o interesse do autor em adequá-los a esse público (RADINO, 2003). De acordo com Radino (2003), na primeira obra publicada de Perrault, Histoires ou contes du temps passé, o autor censura alguns contos da coletânea e termina os demais com uma lição de moral, mostrando uma certa designação educativa.

O conto Pele de asno, que já havia sido escrito pelo autor anteriormente à publicação do livro, foi excluído por ele na publicação da primeira produção literária. O conto traz temas polêmicos e possivelmente considerados inapropriados pelo autor, como o desejo incestuoso do rei por sua filha (RADINO, 2003).

Pele de asno foi posteriormente publicado no livro Contes de ma Mère l'Oye (Contos de mamãe gansa), primeira coletânea de contos para crianças. Ao encontro disso, Bastos (2015, p. 68) defende que "este conto marca o nascimento de um gênero que conhecemos como Literatura Infantil, pois o escritor o endereçou à criança".

Sabendo que, nesse período, a concepção moderna de infância não havia se consolidado, é possível perceber que Charles 
Perrault deu um grande passo no sentido de alcançar, com suas obras, o público infantil. É digno de nota que ele tenha atribuído a autoria do livro a seu filho e o dedicado ao príncipe da França, ambos ainda crianças (HILLESHEIM; GUARESCHI, 2006). Todavia, esses elementos não deixam de compor um cenário que é também marcado por outros que lhe fazem contraste, como o próprio fato dos contos de Perrault retratarem momentos de violência contra mulheres e crianças, como podemos verificar no conto aqui analisado.

O início do conto possui um fragmento que demonstra uma possível preocupação com a infância, expressada pelo autor em forma de verso: "Sem temer, pois, a acusação de que meu tempo emprego mal, o conto Pele de Asno, em versão integral, narro para geral satisfação" (PERRAULT, 2015, p. 127). Considerando que o autor foi um grande intelectual do período em que viveu, esse fragmento demonstra que ele percebia o conteúdo do conto como algo pesado para a nova representação de infância que vinha se consolidando, ou até o incesto como algo impróprio não só no que se refere à infância. A questão para refletir é: em sua primeira publicação o conto foi censurado, mas o que faz com que na segunda ele seja agregado à coletânea? Cabe lembrar que esse momento histórico é permeado por modificações em torno da sexualidade e da infância. O autor costumava censurar aspectos relacionados à sexualidade e à cultura pagã, pensando seus escritos em prol da corte (RADINO, 2003).

Esse trecho retirado do livro demonstra uma justificativa do autor na escolha do texto, como se ele fosse agregado ao livro pelo fato de que foi solicitado pelo público e não por escolha própria, reforçando que o autor percebia que estava em um período de modificação social e que essa transição poderia fazer com que Pele de asno logo fosse julgado inapropriado. Considerando que, segundo Méllo (2006, p. 45), "a prevalência da moralidade cristã na constituição e aplicação das leis favoreceu a ilegalidade de várias atividades sexuais, tais como o adultério, a bigamia, o incesto, a 
sodomia", esse aspecto estava fortemente presente no momento histórico retratado por Perrault.

O conto mencionado anteriormente tem como seu ponto alto o desejo incestuoso do rei pela sua filha. No conto, com o intuito de persuadir a menina, o rei oferece todas as fontes de sua riqueza para satisfazer os caprichos exigidos pela princesa. Orientada pela fada madrinha, a menina procurava pedir coisas aparentemente impossíveis, tal era seu horror em relação à ideia de se casar com o próprio pai. A narrativa transcorre incluindo várias passagens que ilustram essa tentativa da protagonista de fazer o pai fracassar em oferecer suas exigências, mas o rei obtém êxito em tudo, o que leva a princesa a fugir para longe e trabalhar escondida sob a pele de um asno. Essa condição subalterna da protagonista segue até o momento em que ela encontra um príncipe e casa-se com ele. Somente assim seu pai passa a julgar negativamente seu próprio desejo incestuoso e volta a ter uma relação com a filha portando-se como pai.

Nesse conto, podemos observar alguns pontos estranhos a uma realidade moderna e ocidental. Primeiro porque, ao que tudo indica, a protagonista do conto é uma jovem menina. Defendemos tal percepção pois, na Idade Média, o Direito Canônico regulamentou como idade mínima para casar os 12 anos para as mulheres e os 14 anos para os homens. Isso decorre da maturação do corpo para a consumação do casamento, ou seja, para atingir o objetivo de procriação (SOUSA, 2003-2004). No entanto, encontram-se indícios de que, no caso das famílias reais, essa idade poderia ser ainda menor, em torno de 8 anos. Podemos observar este fato no exemplo do casamento que firmou a união das linhagens reais entre representantes de Portugal e de Castela, realizado durante a baixa Idade Média: “D. Isabel, filha bastarda d'el-rei D. Fernando, que houvera antes que casasse, com o conde D. Affonso, filho d'el-rei D. Henrique, sendo ella então de idade de oito anos e andava em nove, e elle haveria até dezoito" (RUIZ, 1989 apud LOURENÇO, 2013). 
Mas o elemento desse conto que mais confronta a representação de infância atual é o incesto. Esse é aqui "entendido como a proibição da união matrimonial ou sexual entre parentes" (PRUDENTE, 2015, p. 55-56). Porém, Silva e Mendes (2015) expõem que o incesto era bastante retratado nos contos do período medieval, porque era uma prática recorrente entre a população da época. Segundo as autoras, o tema, que já estava presente no Antigo Testamento, foi retomado pela Igreja Católica nesse período.

Richards (1993), em seu livro Sexo, desvio e danação: As minorias na Idade Média, esclarece que alguns autores da época classificavam penitências para os atos considerados pecaminosos a partir dos dogmas da Igreja Católica "em ordem crescente de gravidade" (RICHARDS, 1993, p. 41), observando tal sequência: "o incesto, a sodomia e a bestialidade, o adultério, a fornicação e a masturbação" (RICHARDS, 1993, p. 41).

É importante lembrar que o período em que Perrault viveu não foi a Idade Média, mas levando em conta que os contos escritos por ele foram retirados da tradição oral camponesa produzida ao longo dos séculos, e que o período vivido pelo autor é marcado por um processo complexo de transição para a Modernidade, deve-se considerar a Idade Média como uma referência relevante para a análise. Observa-se, assim, que o contexto da história narrada por Perrault apresenta elementos que podem ser associados à sociedade medieval, quando a Monarquia prosperava, sendo possível constatar isso observando os personagens: um rei aristocrático e soberano, uma rainha e a filha, ou seja, uma família real com características próximas às observadas naquele período.

Além do evidente poder do soberano, a Igreja também era bastante relevante, a sociedade medieval caracteriza-se como "unanimemente cristã" (ARIÈS, 2014, XV). Segundo Silva e Mendes (2015):

a Igreja Católica criou diversas regras para o casamento durante esse período com o intuito de controlar essas uniões e uma das formas de exercer esse controle foi condenando o incesto em todas as instâncias possíveis. (SILVA; MENDES, 2015, p. 249). 
As modificações ocorridas na Modernidade, o protagonismo da burguesia, por exemplo, iniciado na segunda parte da Idade Média e fortalecido na Idade Moderna, período histórico vivido por Perrault, espalhou "uma cultura mais laica e mais realista" (CAMBI, 1999, p. 162), mas não anulou totalmente o poder exercido pela Igreja.

A moral estabelecida pela Igreja percebe o sexo como procriação. Ou seja, na época toda a relação sexual ou excitação que não tivesse tal objetivo era considerada pecado. A ideia era a de que tal prática "se opõe contra a ordem natural das coisas" (MÉLLO, 2006, p. 115).

Nessa perspectiva, Méllo (2006) afirma um paradoxo no que se refere à proibição do incesto, pois a Igreja defende que práticas sexuais que não objetivem a reprodução devem ser passíveis de punição, por não seguirem a ordem natural da vida humana. Essa mesma natureza, no entanto, "impõe a reprodução da espécie humana à aliança entre um macho e uma fêmea, mas não indica nenhuma regra que organize essa união de uma determinada maneira" (MÉLLO, 2006, p. 122). Ou seja, o paradoxo expresso pelo autor está no indivíduo ser punido por voltar-se a algo que faz parte da sua natureza, o que a Igreja, de algum modo, defende.

O autor traz ainda a teoria criada por Freud sobre o Complexo de Édipo, situando que este, baseado em seus estudos acerca do tabu do incesto, defende a ideia de que o primeiro desejo sexual da criança é referente à própria mãe. Após vivenciar o Complexo de Édipo, o indivíduo vai adaptando-se aos costumes e regras sociais.

No conto, o desejo incestuoso e os comportamentos a ele associados manifestos pelo pai fizeram a filha fugir para longe. Essa fuga é vista como algo simbólico para Corso e Corso (2006), pois eles entendem que o conto representa o complexo de Édipo feminino. A leitura psicanalítica desses autores refere-se ao início da feminilidade, do sair de casa na idade adulta, deixando a infância de lado, da procura do parceiro e do ato sexual. 
Ou seja, depois de superar o complexo de Édipo, a menina passa a adaptar-se aos costumes e às regras de seu contexto e julgar a escolha do pai como algo errado. Isso pode ser reparado em alguns momentos do conto: "Mas a princesinha se atrista ao saber daquela mania e pelos cantos chora noite e dia [...] Sentindo-se muito infeliz, vai ver o que a madrinha diz" (PERRAULT, 2015, p. 131). A própria madrinha, ao responder, demonstra desaprovação quanto à atitude do rei na seguinte fala: “Ceder a uma tal insistência seria completa demência" (PERRAULT, 2015, p. 131).

Perrault reforça ainda que "ela pôs-se a chorar um destino tão triste" (PERRAULT, 2015, p. 134) e ao fim a princesa acaba "fugindo àquele mal tão próximo e terrível" (PERRAULT, 2015, p. 134). Como é possível perceber, o autor frisa em vários momentos a desaprovação ao incesto. Isso se dá porque, na época de Perrault, o sentimento de infância começa a encontrar seu lugar e a família começa a estruturar-se de forma mais próxima ao que se entende atualmente (MELO, 2008).

Nesse sentido, os assuntos mais comuns na Idade Média estavam começando a causar certo estranhamento na época vivida pelo autor, e é a partir disso que se pode ter clareza da postura de Perrault em censurar alguns textos e até de tentar excluir Pele de asno de sua primeira publicação em livro. Todavia, "a sociedade francesa da época, ao mesmo tempo em que refletia sobre as questões do incesto, abria um espaço para que se representasse o tema nos contos e estórias para as crianças" (MELO, 2008, p. 23).

Em outras palavras, o horror da Igreja ao incesto ou até mesmo como consenso da sociedade atual, não é algo inato; foi uma concepção construída ao longo dos séculos através das relações sociais. Méllo (2006, p. 121) afirma ainda que "se houvesse uma repugnância natural, não haveria necessidade de proibi-lo", mencionando ainda que atualmente pode-se afirmar que "não há no domínio humano ato natural que não seja cultural" (SIMONIS, 1968, p. 35-36, apud MÉLLO, 2006). 
O que a Igreja procurava mostrar é que a fé religiosa e a sexualidade não se relacionavam (MÉLLO, 2006). Se existiam explicitamente textos religiosos que puniam certas práticas, pode-se deduzir que de alguma forma elas costumavam acontecer. Para Prudente (2015), nas cortes, o incesto era muito comum na tentativa de manter a riqueza e o poder na mesma família.

Diante das leis da Igreja, o rei do conto poderia ser punido por seu comportamento incestuoso? Não, porque "determinações canônicas, criadas com vistas ao controle das alianças e transferências aristocráticas, são apropriadas pelo discurso régio e utilizadas ao seu favor, ao empregá-las no interior de um discurso que visava a justificativa de seu poder" (PRUDENTE, 2015, p. 72). Ou seja, o rei e suas necessidades eram soberanas e possíveis dentro das leis estabelecidas pela Igreja.

No conto Pele de asno essa afirmação se confirma no seguinte trecho: "Achou até um casuísta que seu caso afirmou ter fundamentação" (PERRAULT, 2015, p. 131). Assim, o próprio rei, considerando que seu ato seria julgado pecaminoso, precisou da ajuda de um casuísta para estudar seu caso e, partindo das leis da Igreja, elaborar uma explicação para seu comportamento incestuoso.

O conto nos mostra que a menina era filha única do rei. Se não se casasse com o pai, a riqueza sairia da família nas próximas gerações. "A narrativa expõe os critérios de sucessividade ao trono, definidos pelo poder masculino que impera na sociedade retratada na narrativa" (MICHELLI, 2013, p. 5) e, assim sendo, além da paixão sentida pelo rei e do fato de a menina ser a única mulher mais doce e bonita que sua mãe, a riqueza e o poder permaneceriam na família se o casamento dos dois se concretizasse.

Mesmo que a idade de Pele de Asno não tenha sido exposta no conto, ao ser identificada como menina, deveria ser ainda uma criança quando o pai quis desposá-la ou até quando se casou. Porém, Ariès (2014) menciona que na época era normal ver meninas por volta dos 13 anos casadas e agindo como mulheres adultas, tendo total noção de seus afazeres. 
Entre o povo, contudo, dificilmente o incesto passava impune, já que além dos praticantes serem punidos publicamente, para servir de exemplo para os demais, o ato contaminaria todo o povo. Desse modo, o incesto era frequentemente denunciado, o que dificultava a prática (MÉLLO, 2006).

É possível constatar, então, que tanto o incesto, mesmo que considerado pecaminoso, quanto o casamento com uma criança, eram situações recorrentes no contexto histórico representado por Perrault. É interessante apontar para o fato de "que as atividades sexuais entre adultos e crianças nem sempre foram consideradas especialmente ilegais" (MÉLLO, 2006, p. 45). Os crimes sexuais existiam, mas as punições dadas aos adultos que os cometiam não levavam em consideração se a vítima era adulta ou criança. Com esses episódios, é possível notar que a visão corrente na época sobre a infância e as práticas sexuais envolvendo crianças não era equivalente à dominante na atualidade.

Considerando essas colocações, justifica-se afirmar que, mesmo que a menina do conto não quisesse casar-se com o pai, era improvável que seu desejo fosse respeitado, tendo em vista que seu progenitor era, além de adulto (cuja vontade prevalecia em relação à da criança), um rei. Assim, pode-se compreender o motivo de sua fuga ou até mesmo das condições colocadas por ela para o indesejado casamento.

\section{Conclusão}

O presente artigo objetivou discutir os conceitos de contos de fadas, infância e sexualidade para, posteriormente, analisar o conto Pele de asno de Charles Perrault, no intuito de descrever a forma como a infância e a sexualidade eram percebidas naquele contexto. A primeira seção foi dedicada a esclarecer a escolha de utilizar o conto como subsídio para compreender essas questões. A segunda buscou analisar o conto Pele de asno, considerando-o 
um material rico em informações sobre o contexto histórico no qual foi escrito, e também sobre as representações de infância e sexualidade possíveis de serem acessadas por meio dessa narrativa. Para tanto, dedicamo-nos a examinar o próprio texto para detectar trechos que dessem pistas de elementos da história a serem analisados, buscando, num segundo momento, articular a análise desses achados com apontamentos feitos por autores cujas contribuições poderiam nos ajudar a compreender e problematizar a organização social do contexto histórico retratado por Perrault.

Conforme destacado, o conto em questão foi a primeira narrativa adaptada ao público infantil, já que no período histórico anterior à publicação o sentimento de infância era inexistente. Dessa forma, é por meio desse e de outros contos de fadas que nasce uma literatura voltada ao público infantil.

Antes de analisar a representação de infância presente no conto de Perrault, foi possível compreender, por meio da literatura científica consultada, a infância como fenômeno social, ou seja, perceber o processo de construção de um "sentimento de infância" (ARIÈS. 2014). Esse sentimento, que nem sempre existiu, foi se constituindo a partir de processos sociais e históricos. Da mesma forma, a sexualidade - mesmo a adulta - e o modo como os indivíduos a experimentam e significam estão intrinsecamente ligados a processos históricos e construções sociais.

Por meio da análise do conto, constatou-se que a infância e a sexualidade estão ali representadas, e a leitura da forma como eram percebidas, na época, pode ser feita não apenas atentando-se aos comportamentos da protagonista. É possível dizer que o enredo dessa história gira em torno da sexualidade das personagens e do modo como escolhem lidar com seus desejos. Outro aspecto possível de identificar é a soberania do rei e da Igreja ao tomar decisões no período histórico retratado por Perrault. Isso é perceptível através da presença de personagens nobres e a soberania exercida por ele, bem como a importância dada a leis elaboradas pela Igreja Católica e o poder que ela detinha sobre os 
Pele de asno: do texto ao contexto

Ana Carolina Stakonski • Ivone maria mendes silva

demais. Esses aspectos estão claramente presentes no conto Pele de asno.

Além disso, a análise do conto possibilitou a realização de uma discussão sobre o incesto. Na Idade Média, tal prática era expressamente proibida pela Igreja. Considerando tal proibição, o indivíduo que cometesse esse pecado era punido publicamente para servir de exemplo negativo aos demais. No entanto, no conto, o rei deseja manter relação incestuosa com a própria filha. Assim, a análise do conto possibilitou a reflexão acerca dos desejos do rei confrontados com as leis da Igreja. Da mesma forma, tornou possível perceber a forma como Perrault demonstrou o desgosto da princesa com tal desejo do pai.

A infância retratada no conto demonstra a falta de percepção desta fase como distinta e permeada de cuidados como a concebemos atualmente. No que se refere à sexualidade, o conto demonstra que, naquele contexto histórico, as crianças não eram privadas de tomar conhecimento ou participar de atividades sexuais, mesmo se estas envolviam adultos. Práticas que, na atualidade, são consideradas inadequadas, abusivas e ilegais em nossa sociedade.

\section{Referências}

ANDRADE, Celeste de. A literatura no ensino da história da Bahia: a obra de Jorge Amado. 1996.

ARIÈS, Phillipe. História social da criança e da família. Rio de janeiro: LTC, 2014.

BASTOS, Renilda. Literatura Infantil: uma leitura da história.

Revista Sentidos da cultura, Belém-PA, Ano 2, jan-jun, p. 65-80, 2015.

CAMBI, Franco. A história da pedagogia. São Paulo: FEU, 1999.

CANTON, Katia. Os contos de fadas e a arte. São Paulo: Prumo, 2009. 
CARVALHO, Renata. Contos de fadas: um percurso histórico-literário das imagens da mulher. 2009. 142 f. Dissertação (Mestrado em Estudos Comparados de Literaturas de língua Portuguesa) - Faculdade de Filosofia, Letras e Ciências Humanas, Universidade de São Paulo, São Paulo, 2000.

CORAZZA, Sandra. Infância e educação: era uma vez... Quer que conte outra vez? Petrópolis: Vozes, 2002.

CORSO, Diana; CORSO, Mario. Fadas no divã: psicanálise nas histórias infantis. Porto Alegre: Artmed, 2006.

DARNTON, Robert. 0 grande massacre de gatos: e outros episódios da história cultural francesa. São Paulo: Paz e terra, 2015

DEBALD, Blasius; SILVA, Adriana; OLIVEIRA, Maria. de. A compreensão do contexto histórico a partir dos contos de fadas no século XXI. Pleiade, Foz do Iguaçu, v. 14, n. 14, jul./dez., p. 68-76, 2013.

FERREIRA, Cristina. José de Alencar e a emancipação nas cartas de Erasmo (1865-1871). In: $7^{\circ}$ Encontro Escravidão e Liberdade no Brasil Meridional, 7., 2015, Curitiba. Anais [...]. Curitiba: UFPR, 2015. p. 1-13. FREUD, Sigmund. A sexualidade infantil. In: FREUD, Sigmund. Três ensaios sobre a teoria da sexualidade (1905). Edição Standard Brasileira das obras completas, v. 13, p.106-141. Rio de Janeiro: Imago, 1976. Disponível em: http://conexoesclinicas.com.br. Acesso em: 13 dez. 2019.

FREUD, Sigmund. A dissolução do complexo de Édipo. In: FREUD, S. Edição standard brasileira das obras psicológicas completas de Sigmund Freud (Vol. 19). Rio de Janeiro: Imago, 1996. p. 189-199. HEYWOOD, Colin. Uma história da infância: da Idade Média à Época Contemporânea no Ocidente. Porto Alegre: Artmed, 2004.

HILLESHEIM, Betina; GUARESCHI, Neuza. Contos de Fadas e Infância(s). Educação e Realidade, Porto Alegre, v. 31, n. 1, p. 107-126, 2006. LAPLANCHE, Jean; PONTALIS, Jean-Bertrand. Vocabulário da Psicanálise. São Paulo: Martins Fontes, 2001. 
LOURO, Guacira. O corpo educado. Pedagogias da Sexualidade. 3. ed. Belo Horizonte: Autêntica, 2010. v. 01.

MÉLLO, Ricardo. A construção da noção de abuso sexual infantil. Belém: EDUFPA, 2006.

MELO, Liliane. Parentalidade e conjugalidade: a experiência de mulheres que tiveram um filho vítima de incesto. 2008. $117 \mathrm{f}$. Dissertação (Mestrado em Psicologia Clínica) - Faculdade de Psicologia, Universidade Católica de Pernambuco, Recife, 2008. Disponível em: http://www.unicap.br/tede/tde_arquivos/1/TDE-2010-0311T105545Z-199/Publico/dissertacao_liliane_melo.pdf. Acesso em: 13 set. 2016.

\section{MICHELLI, Regina. Entretecendo histórias à roda do feminino e} do masculino na literatura infantil da tradição. In: XIV Simpósio Nacional de Letras e Linguística, 14.; IV Simpósio Internacional de Letras e Linguística, 4., 2013, Uberlândia. Anais [...]. Uberlândia: EDUFU, 2013. v. 3. p. 1-17. Disponível em: http://www.ileel.ufu.br/anaisdosilel/pt/arquivos/silel2013/3098.pdf. Acesso em: 14 set. 2016.

PERRAULT, Charles. Contos de mamãe gansa. Porto Alegre: L\&PM, 2015.

PRUDENTE, Luisa. Incesto, Parentesco e Linhagem no século XIII: A normativa matrimonial das Siete Partidas de Afonso X. Signum, Associação Brasileira de Estudos Medievais cidade, v. 16, n. 2, p. 51-72, 2015.

RADINO, Glória. Contos de fadas e realidade psíquica: a importância da fantasia no desenvolvimento. São Paulo: Casa do psicólogo, 2003.

RICHARDS, Jeffrey. Sexo, desvio e danação: as minorias na Idade Média. Rio de Janeiro: Jorge Zahar, 1993.

RUIZ, Teófilo F. Fiestas, Torneos y símbolos de realeza em la Castilla del siglo XV. Las fiestas de Valladoilid de 1428. In: LOURENÇO, Ana L. P. Imagem e legitimação nas cerimônias régias da Baixa Idade Média Portuguesa. 2013. Trabalho de Conclusão de Curso (Licenciatura/ Bacharelado em História) - Institutos de Ciências Humanas Departamento de Historia, Universidade de Brasília, Brasília, 2013. 
Pele de asno: do texto ao contexto

Ana Carolina Stakonski • Ivone maria mendes silva

SILVA, Daniele; MENDES, Franciele. Representações do corpo feminino em "Das Mädchen Ohne Hände": feudalismo, religiosidade e incesto. Nonada: letras em revista, Porto Alegre, v. 24, n. 24, p. 243-258, 2015. SOUSA, Itamar de. A mulher na idade média: a metamorfose de um status. Revista da FARN, Natal, v. 3, n. 1/2, p. 159 - 173, jul. 2003/jun. 2004. 